\title{
BOND STRENGTH OF HARD CHAIRSIDE RELINE RESINS TO A RAPID POLYMERIZING DENTURE BASE RESIN BEFORE AND AFTER THERMAL CYCLING
}

\author{
RESISTÊNCIA DE UNIÃO DE RESINAS RÍGIDAS PARA REEMBASAMENTO IMEDIATO A RESINA \\ PARA BASE DE PRÓTESE DE RÁPIDA POLIMERIZAÇÃO ANTES E APÓS TERMOCICLAGEM
}

\author{
Karin Hermana NEPPELENBROEK ${ }^{1}$, Ana Cláudia PAVARINA², Mauricio Neves GOMES ${ }^{3}$, \\ Ana Lucia MACHADO ${ }^{4}$, Carlos Eduardo VERGANI ${ }^{4}$
}

\begin{abstract}
1- DDS, MSc, PhD, Pos Doctor Researcher, Department of Dental Materiais and Prosthodontics, Araraquara Dental School, São Paulo State University, São Paulo, Brazil.

2- DDS, MSc, PhD, Assistant Professor of Removable Prosthodontics, Department of Dental Materiais and Prosthodontics, Araraquara Dental School, São Paulo State University, São Paulo, Brazil.

3- DDS, MSc student, Department of Dental Materiais and Prosthodontics, Araraquara Dental School, São Paulo State University, São Paulo, Brazil.

4- DDS, MSc, PhD, Associate Professor of Removable Prosthodontics, Department of Dental Materiais and Prosthodontics, Araraquara Dental School, São Paulo State University, São Paulo, Brazil.
\end{abstract}

Corresponding address: Ana Cláudia Pavarina - Araraquara Dental School- São Paulo State University - Rua Humaitá, $\mathrm{n}^{\circ} 1680$ - Araraquara São Paulo - Brazil- CEP: 14801-903 - Phone:\#55\#016\#33016410-Fax: \#55\#016\#33016406 - e-mail: pavarina@foar.unesp.br

Received: June 12, 2005 - Modification: September 25, 2006 - Accepted: October 27, 2006

\begin{abstract}
$P$

urpose: This study assessed the shear bond strength of 4 hard chairside reline resins (Kooliner, Tokuso Rebase Fast, Duraliner II, Ufi Gel Hard) to a rapid polymerizing denture base resin (QC-20) processed using 2 polymerization cycles (A or B), before and after thermal cycling. Materials and Methods: Cylinders ( $3.5 \mathrm{~mm}$ x $5.0 \mathrm{~mm}$ ) of the reline resins were bonded to cylinders of QC-20 polymerized using cycle A (boiling water-20 minutes) or B (boiling water; remove heat-20 minutes; boiling water-20 minutes). For each reline resin/polymerization cycle combination, 10 specimens (groups CAt e CBt) were thermally cycled ( 5 and $55^{\circ} \mathrm{C}$; dwell time 30 seconds; 2,000 cycles); the other 10 were tested without thermal cycling (groups CAwt ad CBwt). Shear bond tests $(0.5 \mathrm{~mm} / \mathrm{min})$ were performed on the specimens and the failure mode was assessed. Data were analyzed by 3-way ANOVA and Newman-Keuls post-hoc test $(\alpha=.05)$. Results: QC-20 resin demonstrated the lowest bond strengths among the reline materials $(P<.05)$ and mainly failed cohesively. Overall, the bond strength of the hard chairside reline resins were similar $(10.09 \pm 1.40$ to $15.17 \pm 1.73 \mathrm{MPa}$ ) and most of the failures were adhesive/cohesive (mixed mode). However, Ufi Gel Hard bonded to QC-20 polymerized using cycle A and not thermally cycled showed the highest bond strength $(P<.001)$. When Tokuso Rebase Fast and Duraliner II were bonded to QC-20 resin polymerized using cycle A, the bond strength was increased $(P=.043)$ after thermal cycling. Conclusions: QC-20 displayed the lowest bond strength values in all groups. In general, the bond strengths of the hard chairside reline resins were comparable and not affected by polymerization cycle of QC-20 resin and thermal cycling.

Uniterms: Shear strength; Acrylic resins; Denture liners.
\end{abstract}

\footnotetext{
RESUMO

$O$

bjetivo: Esse estudo avaliou a resistência de união ao cisalhamento de 4 resinas rígidas para reembasamento imediato (Kooliner, Tokuso Rebase Fast, Duraliner II, Ufi Gel Hard) a uma resina para base de prótese de rápida polimerização (QC-20) submetida a 2 ciclos de polimerização (A e B), antes e após termociclagem. Materiais e Métodos: Cilindros (3,5 mm x 5,0 mm) das resinas reembasadoras foram unidas aos cilindros de resina QC-20 polimerizados pelo ciclo A (água fervente - 20 minutos) ou B (água fervente; remoção do calor-20 minutos; água fervente-20 minutos). Para cada combinação resina reembasadora/ciclo de polimerização, 10 corpos-de-prova (grupos CAt e CBt) foram termociclados (5 e $55{ }^{\circ} \mathrm{C}$; intervalo de tempo 30 segundos; 2.000 ciclos); os outros 10 foram testados sem termociclagem (grupos CAwt e CBwt). Os testes de resistência de união ao cisalhamento $(0,5 \mathrm{~mm} / \mathrm{min})$ foram realizados sobre os corpos-de-prova e o tipo de falha avaliado. Os dados foram analisados por análise de variância (ANOVA) e teste de Newman-Keuls $(\alpha=0,05)$. Resultados: A resina QC-20 demonstrou a menor resistência de união entre os materiais reembasadores $(\mathrm{p}<0,05)$ e apresentou falhas predominantemente coesivas. De modo geral, os valores de resistência de união das resinas rígidas para reembasamento imediato foram similares $(10,09 \pm 1,40$ a $15,17 \pm 1,73 \mathrm{MPa})$ e a maioria de falhas foram do tipo adesiva/coesiva (mista). Entretanto, a resina Ufi Gel Hard unida à resina QC-20 polimerizada pelo ciclo A e não termociclada apresentou a maior resistência de união $(\mathrm{p}<0,001)$. Quando as resinas Tokuso Rebase Fast e Duraliner II foram unidas à resina QC-20 polimerizada pelo ciclo A, a resistência de união aumentou $(\mathrm{p}=0,043)$ após a termociclagem. Conclusões: QC-20 apresentou os menores valores de resistência de união em todos os grupos. Em geral, os valores de resistência de união das resinas reembasadoras rígidas foram comparáveis e não foram influenciados pelo ciclo de polimerização da resina QC-20 e pela termociclagem.

Unitermos: Resistência ao cisalhamento; Resinas acrílicas; Reembasadores de dentadura.
} 


\section{INTRODUCTION}

Relining ill-fitting removable dentures improves their stability, support and retention ${ }^{10,14}$. A denture may be relined as a laboratory procedure or at the chairside in the dental clinic. The direct relining of denture bases is carried out in the mouth with self-curing reline resins, avoiding the need for patients to be without their dentures for any period, unlike most laboratory procedures ${ }^{10}$. Because of the simplicity of the technique and the good fit obtained, this method has been frequently used to prolong the life of reasonable dentures ${ }^{10,14}$, particularly when the construction of a new one is either not possible or suitable due to health of the patient or the condition of the denture-bearing tissues not being appropriate.

Notwithstanding the temporary use of the direct relining system, adequate bond strength between the reline resin and the denture base material is essential to prevent proliferation of microorganisms at their junction, staining, and failure at the bond site, which may result in delamination of the reline material ${ }^{2,3,10,12}$. Recent hard chairside reline resins contain a variety of methacrylate monomers with relatively greater molecular weight than methyl methacrylate. This may influence the extent of penetration of monomers from reline resins into the denture base resin, which is essential to form an interwoven polymer network ${ }^{3,15,26}$, and compromise the bond strength between the two materials. The denture base surface treatment before relining ${ }^{7,13,19,29}$ as well as the composition and type of reline and denture base resins used may also affect the bond strength ${ }^{2,26}$. Rapid polymerizing denture base acrylic resins, which are processed by short polymerization cycles, gives a considerable saving on the laboratory time $e^{4,6,11}$ compared with the conventional heatpolymerizing denture base materials with longer polymerization cycles. The rapid polymerizing techniques may use short or reverse cycles ${ }^{9}$. It has been reported that the short polymerization cycles of rapid polymerizing denture base acrylic resins produce high levels of residual monomer ${ }^{1,8,9}$ thus resulting in lower mechanical properties ${ }^{14,16,25}$. Moreover, the amount of residual monomer in the denture base acrylic resin may possibly influence the cross-linkage of the surface molecules between the parent acrylic resin and the new material $^{2}$ and, consequently, the bond strength. However, no information could be identified by the authors describing the effect of different short polymerization cycles on the bond strength between denture base and reline resins.

Another aspect that may influence the bond strength between denture base and reline materials is the effect of thermal cycling ${ }^{15}$. During clinical use, the temperature of a dental prosthesis may vary considerably because of the intake of hot and cold food and drinks ${ }^{17}$, and the use of warm or hot water in cleaning the prosthesis ${ }^{21}$. Also, thermal cycling promotes the hydration of specimens, which further simulates the oral condition ${ }^{22}$. The absorbed water molecules, which act as a plasticizer ${ }^{23,24}$ may percolate directly at the bond interface and decrease the bond strength between the denture base and the reline resin ${ }^{5,15}$. On the other hand, during thermal cycling, the residual monomer, which also acts as a plasticizer, may be reduced by leaching into the water ${ }^{27,30}$ and further polymerization reaction ${ }^{12}$ thus increasing the bond strength of reline resin to denture base. Nevertheless, little is known on the effect of thermal cycling on the bond strength between hard reline and denture base materials ${ }^{15}$.

This study evaluated the bond strength of 4 hard chairside reline resins to a heat- polymerizing denture base resin processed by 2 different polymerization cycles, before and after being thermally cycled. The bond strength of the denture base resin relined with the same material was also evaluated for comparison. The hypotheses tested were that the mean bond strengths would be different for the reline materials and the denture base resin polymerization cycles used, and that the bond strength between these materials would be decreased by thermal cycling.

\section{MATERIALS AND METHODS}

Four hard chairside reline resins and one heat polymerizing denture base resin were selected for this study. The name of the resins, manufacturers, compositions, powder to liquid ratios, and the polymerization conditions recommended by the manufacturers are listed in Table 1 . The 4 brands of hard chairside reline resins (Kooliner, Tokuso Rebase Fast, Duraliner II, Ufi Gel Hard) used in the present study were chosen because they have different chemical compositions (Table 1). Material QC-20 was selected as representative of denture base acrylic resins processed by using a boiling water method.

In preparing the specimens, 200 PVC tubes (Tigre SA Tubos e Conexões, Joinville, SC, Brazil) were used for fabrication of wax (Wilson, Polidental Indústria e Comércio LTDA, São Paulo, SP, Brazil) cylinders (20 mm X 20 mm), which were then invested in flasks (Jon 3.0; Jon Produtos Odontológicos, São Paulo, SP, Brazil) using Type IV dental stone (Troquel Quatro, Polidental Indústria e Comércio LTDA, São Paulo, SP, Brazil). After elimination of the wax, the denture base resin QC-20 was mixed, packed into the PVC tubes using a hydraulic press (Vipi Dental, Pirassununga, São Paulo, SP, Brazil) and polymerized according to one of the cycles suggested by the manufacturer (A or B). Half of the denture base resin cylinders $(n=100)$ was polymerized in water bath using cycle A and the other half was processed in water bath according to cycle B (Table 1). After polymerization, the processed flask was allowed to cool at room temperature for 30 minutes and then was placed under running water for 15 minutes. The specimens were removed from the flasks and stored in distilled water at $37 \pm 1^{\circ} \mathrm{C}$ for 502 hours $^{23}$. After water storage, the denture base resin surfaces to be bonded were smoothed on 240-grit silicone carbide paper (3M do Brazil, Ribeirão Preto, SP, Brazil), in an automatic grinding and polishing unit (Metaserv 2000, model 95-2829, Buehler UK Ltd., Coventry, England) at 350 r.p.m. for 40 seconds, to simulate clinical relief of the denture base for bonding of the reline resins. The 240 -grit paper has been used for surface preparation in investigations on the bond strength between hard chairside reline and denture base acrylic resins ${ }^{5,7,25}$. 
The surfaces were then brushed with liquid detergent (Limpol, Bombril-Cirio, São Paulo, SP, Brazil) for 20 seconds, washed in distilled water, and blot-dried. Thereafter, surfaces were treated according to the manufacturer's instructions for each hard chairside reline material, with the exception of material Kooliner, for which the bonding sites were prepared by painting the surfaces with QC-20 monomer for 180 seconds. This procedure was based on the results of a previous study ${ }^{13}$ which demonstrated that wetting the bonding surface with the denture base resin monomer promoted the highest flexural bond strength for material Kooliner. A masking tape with a 3.5-mm diameter circular opening was placed on the treated denture base surfaces to provide a uniform bonding area $\left(9.62 \mathrm{~mm}^{2}\right)$.

An especially designed metal split mold having a circular opening (3.5-mm diameter X 5.0-mm length) was used for the relining procedures. The denture base cylinder was placed in the mold and secured via screws, so that the metal mold opening position coincided with the masking tape opening position. The self-curing reline materials were then mixed according to the manufacturers' instructions, and inserted into the 3.5-mm X 5.0-mm split mold opening. An acetate sheet was placed over the material, and pressure was applied until polymerization was completed. The screws were loosened, the two parts of the mold were separated and the relined specimen was removed.

When the specimens were relined using the heatpolymerizing acrylic resin QC-20, initially the denture base cylinders were invested in Type IV dental stone to half their length within the first part of the flask. A metal die (3.5-mm diameter and 5.0-mm length) was directly glued to the center of the bonding surface with a small drop of cyanoacrylate glue (Super Bonder, Henkel Loctite Products, Rocky Hill, CT, USA). Low viscosity silicone rubber impression material (Oranwash L, Zhermack, Badia Polesine, Rovigo, Italy) was injected onto the die, and high viscosity silicone impression material (Zetaplus, Zhermack, Badia Polesine, Rovigo, Italy) was then applied. The second part of the flask was positioned and filled with Type IV dental stone, which was allowed to set. The flask was opened, the metal die was removed, and the bond surface was prepared as described and treated with QC-20 monomer for 180 seconds $^{29}$. The masking tape was

TABLE 1- Materials tested

\begin{tabular}{|c|c|c|c|c|c|}
\hline \multirow[t]{2}{*}{ Product } & \multirow[t]{2}{*}{ Manufacturers } & \multicolumn{2}{|c|}{ Composition } & \multirow{2}{*}{$\begin{array}{l}\text { Powderl } \\
\text { liquid ratio }\end{array}$} & \multirow{2}{*}{$\begin{array}{l}\text { Polymerization } \\
\text { condition }\end{array}$} \\
\hline & & Powder & Liquid & & \\
\hline QC-20 & $\begin{array}{l}\text { Dentsply International Inc., } \\
\text { York, USA }\end{array}$ & $\begin{array}{l}\text { PMMA } \\
\text { BPO }\end{array}$ & $\begin{array}{l}\text { MMA } \\
\text { EGDMA } \\
\text { DMPT }\end{array}$ & $2.3 \mathrm{~g} / 1 \mathrm{~mL}$ & $\begin{array}{l}\text { Cycle A - insert flask in } \\
\text { boiling water, return to boil } \\
\text { and boil for } 20 \text { min } \\
\text { Cycle B - boil water, insert flask, } \\
\text { remove heat for } 20 \text { min, return to } \\
\text { boil and boil for } 20 \text { min }\end{array}$ \\
\hline Kooliner & $\begin{array}{l}\text { Coe Laboratories, Inc., } \\
\text { York, Chicago, III, USA. }\end{array}$ & PEMA & IBMA & $\begin{array}{l}2.1 \mathrm{~g} / \\
1.5 \mathrm{~mL}\end{array}$ & $10 \mathrm{~min}$ at room temperature \\
\hline Duraliner II & $\begin{array}{l}\text { Reliance Dental Mfg. Co., } \\
\text { Worth, III, USA. }\end{array}$ & PEMA & $\begin{array}{l}\text { BMA } \\
\text { EGDMA }\end{array}$ & $\begin{array}{l}2.0 \mathrm{~g} / \\
2 \mathrm{~mL}\end{array}$ & 12 min at room temperature \\
\hline $\begin{array}{l}\text { Tokuso } \\
\text { Rebase } \\
\text { Fast }\end{array}$ & $\begin{array}{l}\text { Tokuyama Dental Corp., } \\
\text { Tokyo, Japan }\end{array}$ & PEMA & $\begin{array}{l}\text { MAOP } \\
1,6- \\
\text { HDMA }\end{array}$ & $\begin{array}{l}2.056 \mathrm{~g} / \\
1 \mathrm{~mL}\end{array}$ & $5.5 \mathrm{~min}$ at room temperature \\
\hline Ufi Gel Hard & Voco, Cuxhaven, Germany & PEMA & $\begin{array}{l}\text { 1,6- } \\
\text { HDMA }\end{array}$ & $\begin{array}{l}3.56 \mathrm{~g} / \\
2 \mathrm{~mL}\end{array}$ & $7 \mathrm{~min}$ at room temperature \\
\hline
\end{tabular}

PMMA, poly (methyl methacrylate); BPo, benzoyl peroxide; MMA, (methyl methacrylate); EGDMA, (ethylene glycol dimethacrylate); DMPT, dimethyl-p-toluidine; PEMA, poly (ethyl methacrylate); IBMA, isobutyl methacrylate; BMA, butyl methacrylate; MAOP, ß-methacryloyl oxyethyl propionate; 1,6 - HDMA, (1,6-hexanediol dimethacrylate); 
positioned on the bonding surface, the denture base acrylic resin QC-20 was mixed, inserted into the silicone mold, and polymerized using cycle A(Table 1 ). After polymerization, the flask was cooled to room temperature and the specimens were deflasked and stored in distilled water at $37 \pm 1^{\circ} \mathrm{C}$ for $50 \pm 2$ hours ${ }^{20}$.

For each reline material (QC-20, Kooliner, Tokuso Rebase Fast, Duraliner II and Ufi Gel Hard), 40 cylinders were prepared, 20 polymerized with cycle A and 20 with cycle B. The 40 specimens of each reline material were then divided into 4 groups $(\mathrm{n}=10)$. Groups CAt and CBt comprised specimens in which the reline materials were bonded to QC-20 cylinders that were polymerized by cycles A and B, respectively, and then submitted to thermal cycling. For groups CAwt and CBwt, the reline materials were bonded to QC-20 cylinders, which were polymerized by cycle A and B, respectively, and tested without thermal cycling (controls). Specimens of CAt and CBt groups were thermally cycled for 2,000 cycles between 5 and $55( \pm 2)^{\circ} \mathrm{C}$ with a dwell time of 30 seconds and a transfer time of 5 seconds using a thermal cycling machine (MSCT-3 plus, Marcelo Nucci-ME, São Carlos, SP, Brazil). Specimens of CAwt and CBwt groups were maintained in distilled water at $37^{\circ} \mathrm{C}$ during the time required to perform the thermal cycling.

Shear bond tests were performed using a universal testing machine (MTS- 810, Material Test System, Éden Prairie, MN, USA) at a $0.5 \mathrm{~mm} / \mathrm{minute}$ crosshead speed and $1 \mathrm{kN}$ load. The load was applied with a knife-edged blade positioned parallel to the material interface. Shear bond strengths (MPa) were calculated by dividing the force required to break the specimen by surface area of adhesion. After shear bond testing, the detached surfaces of specimens were examined by a stereomicroscope (Carl Zeiss, Gottingen, Germany), at original magnification X 40, to assess reline material/denture base resin bonding failure mode. Failures occurring at the relinedenture base resin interface were recorded as adhesive. A combination of failure at the interface and cohesive fracture within the reline or the denture base material was classified as a mixed mode. Failures that occurred within the reline material were considered to be cohesive. Data from shear tests were statistically analyzed by 3-way analysis of variance (ANOVA) with conditions of reline material, denture base resin polymerization cycle, and thermal cycling as independent factors. When there was a significant difference among the means, the Newman-Keuls post hoc comparison test ( $\alpha=.05)$ was applied.

\section{RESULTS}

Three-way ANOVA (Table 2) revealed significant differences in the shear bond strengths for the variables reline material $(P<.001)$, denture base polymerization cycle $(P=.019)$ and thermal cycling $(P=.027)$, and their interaction $(P<.001)$.

From Table 3, it can be observed that the specimens relined with material QC-20 exhibited the lowest mean bond strength values in all groups evaluated $(P<.001)$. When CAwt specimens were compared, material Ufi Gel Hard had the highest shear bond strength $(P<.001)$ among the reline materials. However, for groups CAt, CBwt, and CBt, no significant differences were found between material Ufi Gel Hard and the other self-curing reline resins.

Table 3 also shows that for material Tokuso Rebase Fast, the mean shear bond strength of group CAwt was significantly $(P<.001)$ lower compared with group CBwt. When materials Tokuso Rebase Fast and Duraliner II were bonded to QC-20 resin polymerized using cycle $A$, the mean shear bond strength was significantly $(P=.043)$ increased after thermal cycling (groups CAwt and CAt). For materials Ufi Gel Hard, Kooliner, and QC-20 no significant differences were found among the groups evaluated.

Table 4 lists the type of bond failures observed between the reline materials and denture base resin. Material QC-20 failures were primarily cohesive in nature. For the hard chairside resins (Kooliner, Tokuso Rebase Fast, Duraliner II and Ufi Gel Hard), most of the failures were adhesive/cohesive (mixed mode).

TABLE 2- Results of 3-way ANOVA for shear test

\begin{tabular}{|c|c|c|c|c|c|}
\hline Effects & $\begin{array}{l}\text { Sum of } \\
\text { squares }\end{array}$ & $d f$ & $\begin{array}{l}\text { Mean } \\
\text { square }\end{array}$ & F value & $P$ value \\
\hline Reline material $(\mathrm{A})$ & 1255.294 & 4 & 313.824 & 139.334 & $<.001^{*}$ \\
\hline Denture base polymerization cycle (B) & 12.792 & 1 & 12.792 & 5.679 & $0.019 *$ \\
\hline Thermal cycling $(\mathrm{C})$ & 11.257 & 1 & 11.257 & 4.998 & $0.027^{*}$ \\
\hline$A \times B$ & 23.755 & 4 & 5.939 & 2.637 & $0.037^{*}$ \\
\hline$A \times C$ & 47.634 & 4 & 11.909 & 5.287 & $0.001^{*}$ \\
\hline $\mathrm{B} \times \mathrm{C}$ & 25.632 & 1 & 25.632 & 11.380 & $0.001^{*}$ \\
\hline$A \times B \times C$ & 54.784 & 4 & 13.696 & 6.081 & $<.001^{*}$ \\
\hline Error & 315.324 & 140 & 2.252 & & \\
\hline
\end{tabular}

*Significant difference at $P<.05$. 


\section{DISCUSSION}

The shear bond test used in the present investigation applies a shear load directly to the reline-denture base polymer junction and represents better than tensile load what the reline-denture base polymer interface is subjected to clinically $^{6}$. Also, this test has been used by several investigators to determine the bond strengths of denture base resins to reline materials $s^{7,15,25,26}$.

The hypothesis that the mean bond strengths would be different for the reline materials was accepted. QC-20 resin showed the lowest mean bond strength values among the materials in all experimental conditions evaluated. However, because material QC-20 failures were mainly cohesive, it should be emphasized that actual shear bond strength could not be measured, but rather it may be suggested that the strength of the material is lower than the bond value. Because QC-20 material is a rapid polymerizing denture base resin, the monomer is modified by the addition of a chemical activator (dimethyl-p-toluidine) that begins to decompose in the presence of benzoyl peroxide at the time of mixing of powder and liquid. Therefore, QC-20 resin presents some characteristics of a self-curing acrylic resin because its polymerization is a result of both chemical and thermal activation. Hence, QC-20 resin may display a higher amount of residual monomer, because residual monomer content of heat-polymerizing denture base resins has been demonstrated to be significantly lower than that of self-curing acrylic resins ${ }^{28}$.
Moreover, many studies ${ }^{1,4,8,9,11}$ have demonstrated that residual monomer content varied significantly with polymerizing conditions, and the amount of residual monomer in acrylic resins submitted to short polymerization cycles may be about 10 -fold than that observed with long cycles ${ }^{11}$. The residual monomer acts as a plasticizer in the polymer matrix and causes the formation of more porosity that will also affect the mechanical properties ${ }^{8}$. To achieve low residual monomer levels, polymerization time should be more than 50 minutes $^{8}$. However, for the polymerization cycles A and B, recommended by the manufacturer of QC-20 resin, the processing time did not exceed 50 minutes (Table 1) ) $^{1,8,9}$. Hence, although not examined in the present study, it is likely that the high levels of residual monomer resulting from both chemical composition and polymerization cycles of the QC-20 resin might be responsible for the low failure strengths observed for this material in all experimental conditions. Other investigators have also found that QC-20 resin exhibited significantly lower flexural strength ${ }^{18}$, hardness ${ }^{16}$, and impact strength ${ }^{28}$ than the heat-polymerizing denture base resins evaluated.

To improve bonding between the self-curing reline materials and the denture base resins, manufacturers have recommended surface treatments such as mechanical roughening of the surface of the denture base or the application of proprietary bonding agents before relining ${ }^{25}$. The reline resins Ufi Gel Hard, Tokuso Rebase Fast and Duraliner II have bonding agents supplied by the manufacturers. These bonding agents usually contain

TABLE 3- Mean shear bond strength values ( \pm SD) of reline materials and groups evaluated

\section{Reline material}

\section{CAwt}

\begin{tabular}{llllllll} 
Ufi Gel Hard & $14.62 \pm 2.07 \mathrm{~A}_{\mathrm{a}}$ & $13.82 \pm 2.43 \mathrm{AB}_{\mathrm{a}}$ & $14.10 \pm 2.27 \mathrm{AB}_{\mathrm{a}}$ & $13.36 \pm 1.13 \mathrm{~A}_{\mathrm{a}}$ \\
Kooliner & $11.54 \pm 0.88 \mathrm{~B}_{\mathrm{a}}$ & $11.57 \pm 0.64 \mathrm{~B}_{\mathrm{a}}$ & $11.95 \pm 0.88 \mathrm{~B}_{\mathrm{a}}$ & $12.29 \pm 0.86 \mathrm{~A}_{\mathrm{a}}$ & \\
Duraliner II & $10.77 \pm 2.09 \mathrm{~B}_{\mathrm{a}}$ & $13.46 \pm 1.91 \mathrm{AB}_{\mathrm{b}}$ & $12.89 \pm 2.39 \mathrm{AB}_{\mathrm{ab}}$ & $12.50 \pm 1.15 \mathrm{~A}_{\mathrm{ab}}$ \\
Tokuso Rebase & $10.09 \pm 1.40 \mathrm{~B}_{\mathrm{a}}$ & $15.17 \pm 1.73 \mathrm{~A}_{\mathrm{b}}$ & $14.75 \pm 1.20 \mathrm{~A}_{\mathrm{b}}$ & $14.30 \pm 1.44 \mathrm{~A}_{\mathrm{b}}$ \\
QC-20 & $6.25 \pm 0.70 \mathrm{C}_{\mathrm{a}}$ & $5.91 \pm 0.74 \mathrm{C}_{\mathrm{a}}$ & $6.41 \pm 0.77$ & $\mathrm{C}_{\mathrm{a}}$ & $6.30 \pm 0.73 \mathrm{C}_{\mathrm{a}}$ \\
\hline
\end{tabular}

Test groups

CAt CBwt CBt

Vertically, identical capital letters indicate no significant differences $(P>.05)$ among reline materials. Horizontally, identical subscript small letters indicate no significant differences $(P>.05)$ among test groups.

TABLE 4- Type of failure (\%) between reline materials and denture base resin

\begin{tabular}{llll} 
Reline material & Cohesive & $\begin{array}{c}\text { Type of failures (\%) } \\
\text { Adhesive }\end{array}$ & Mixed mode \\
\hline QC-20 & 87.5 & 2.5 & 10 \\
Ufi Gel Hard & 7.5 & 32.5 & 60 \\
Kooliner & 5 & 45 & 50 \\
Tokuso Rebase Fast & 5 & 37.5 & 57.5 \\
Duraliner II & 5 & 42.5 & 52.5 \\
\hline
\end{tabular}


solvents and/or monomers ${ }^{3}$. Solvents may dissolve the surface of the denture base and promote penetration of the reline acrylic resin into the denture base resin, resulting in the formation of a mixed layer of reline acrylic resin and denture base resin ${ }^{3}$. When the bonding agent is primarily composed by a monomer, it may be observed that the monomer penetrates into the denture base surface and polymerize along with the reline resin ${ }^{3,26}$. Although Kooliner material does not have a related primer, the denture base surface was treated with methyl methacrylate for 180 seconds to achieve optimal bonding ${ }^{13}$. The results from the present investigation suggested that these surface treatments may have facilitated the diffusion and penetration of the reline monomers into the QC-20 resin, because the bond strengths promoted by the self-curing reline resins were similar. Only when QC-20 resin was polymerized using cycle A and not submitted to thermal cycling, material Ufi Gel Hard displayed the highest bond strength among the hard chairside resins. For all other experimental conditions, however, the shear bond strengths obtained with Ufi Gel Hard and other reline materials evaluated were comparable. In addition, microscopic examination of the fracture sites for all materials revealed that most of the specimens had a mixed mode of failure, with crack in QC-20 resin. Moreover, despite some differences in methodology, the results were similar to those reported by Takahashi and Chai $^{26}$. The mean bond strength values ranged from 10.09 to 15.17 MPa and appear to be adequate for relining complete dentures ${ }^{10,14}$. However, clinical studies are needed to confirm whether these bond strengths are capable of withstanding masticatory loads and preventing failures at the denture base/ reline resin interface, particularly for mandibular dentures, which have been found to be considerably more prone to surface loss of reline material than maxillary dentures, regardless of the material used ${ }^{10}$.

The hypothesis that the mean bond strengths would be different for the denture base polymerization cycle used was accepted. Although the bond between the reline materials Ufi Gel Hard, Kooliner, and QC-20 to the denture base resin QC20 was not significantly affected by the polymerization cycle used, for Tokuso Rebase Fast specimens not submitted to thermal cycling, there was a significant difference in the mean bond strength between polymerization cycle A and B. Because cycle $\mathrm{A}$ is shorter than cycle $\mathrm{B}$, it can be hypothesized that a low degree of conversion of QC-20 resin specimens was achieved by using the former. Therefore, polymerization cycle A would be expected to facilitate the diffusion and penetration of the reline monomers into the polymerized QC-20 resin, thus resulting in increased bond. However, surprisingly, for Tokuso Rebase Fast material, polymerization cycle B promoted significantly higher bond strength than cycle A. This finding was not expected and is difficult to explain within the parameters of the present investigation. A microscopic examination of the reline-denture base resin interface as performed by Vallittu, et al. ${ }^{29}$ could be taken into account in further investigations. Nevertheless, regardless of the polymerization cycle used, the mean bond strengths between Tokuso Rebase Fast and QC-20 were in the same range observed by Takahashi and Chai ${ }^{26}$, when Tokuso Rebase
Fast was bonded to 4 different heat-polymerizing denture base acrylic resins.

The hypothesis that the bond strength between the reline and the denture base materials would be decreased by thermal cycling was rejected because no significant differences were found among the groups evaluated for materials Ufi Gel Hard, Kooliner, and QC-20. In addition, when materials Tokuso Rebase Fast and Duraliner II were bonded to QC-20 resin polymerized using cycle $\mathrm{A}$, the mean shear bond strength was significantly increased after thermal cycling. The limited number of thermal cycles used may have accounted for these findings. A reduction in the bond strengths after thermal cycling was expected because the absorbed water molecules ${ }^{8}$ may act as plasticizers within the polymer network and lead to a decrease in both the mechanical strength of the polymerized reline materials ${ }^{23,24}$ and their bond to the denture base $^{5}$. One possible explanation for the increase in bond strength after thermal cycling observed for materials Tokuso Rebase Fast and Duraliner II may be the continuous polymerization reaction where residual monomer molecules are progressively consumed ${ }^{12}$, thus reducing their plasticizing effect. In addition, the content of the residual monomer molecules could have been reduced by release into the water $^{27,30}$ during the thermal cycling and accounted for the increase in the bond strength mean values of Tokuso Rebase Fast and Duraliner II reline resins. Although Ufi Gel Hard and Kooliner materials may also have undergone continuous polymerization and leaching of residual monomer during thermal cycling, an increase in bond strength was not observed. For these materials, the plasticizing effect of the water molecules absorbed during thermal cycling may have counteracted any improvement in bond strength resulting from further polymerization and monomer release. The limitations of this in vitro study include the fact that only one of the available rapid polymerizing denture base resins was evaluated and that only a limited number of thermal cycles was used. Therefore, the behavior of the denture base and reline materials observed in the present investigation may not predict the clinical performance of relined denture bases. Despite these limitations, however, differences between the self-curing reline resins and the QC-20 material could be noted. The relining at the chairside is faster than the indirect laboratory system. When the indirect relining method is selected, the use of rapid polymerizing denture base resins may give a considerable saving on the laboratory time. However, the cohesive failure mode and the low strength values of QC-20 resin observed in the present investigation indicate that during clinical use, this material probably will fracture instead of delaminate away from the denture base.

\section{CONCLUSIONS}

Within the limitations of the laboratory testing conditions of the present study, the following conclusions were drawn:

1. Material QC-20 exhibited the lowest bond strength values in all groups evaluated.

2. Overall, the bond strengths of the hard chairside reline 
resins were comparable. Only when QC-20 resin was polymerized using cycle A and not submitted to thermal cycling, material Ufi Gel Hard showed the highest bond strength.

3. The bond strengths of materials Tokuso Rebase Fast and Duraliner II bonded to QC-20 resin polymerized using cycle A were significantly increased after thermal cycling.

4. For the hard chairside reline resins, most of the failures were adhesive/cohesive (mixed mode), whereas material QC20 mainly failed cohesively.

\section{ACKNOWLEDGMENTS}

This investigation was supported by The State of São Paulo Research Foundation - FAPESP (Grant 01/10223-0) and National Council of Technological and Scientific Development - PIBIC/CNPq (no. 011/05-STA/DTA).

\section{REFERENCES}

1- al Doori D, Huggett R, Bates JF, Brooks SC. A comparison of denture base acrylic resins polymerised by microwave irradiation and by conventional water bath curing systems. Dent Mater. 1988;4(1):25-32.

2- Arena CA, Evans DB, Hilton TJ. A comparison of bond strength among chairside hard reline materials. J Prosthet Dent. 1993;70(2):12631

3- Arima T, Nikawa H, Hamada T, Harsini. Composition and effect of denture base resin surface primers for reline acrylic resins. J Prosthet Dent. 1996;75(4):457-62.

4- Austin AT, Basker RM. Residual monomer levels in denture bases. The effects of varying short curing cycles. Br Dent J. 1982;153(12):424-6.

5- Aydin AK, Terzioglu H, Akinay AE, Ulubayram K, Hasirci N. Bond strength and failure analysis of lining materials to denture resin. Dent Mater. 1999;15(3):211-8.

6- Bartoloni JA, Murchison DF, Wofford DT, Sarkar NK. Degree of conversion in denture base materials for varied polymerization techniques. J Oral Rehabil. 2000;27(6):488-93.

7- Curtis DA, Eggleston TL, Marshall SJ, Watanabe LG. Shear bond strength of visible-light-cured resin relative to heat-cured resin. Dent Mater. 1989;5(5):314-8.

8- Dogan A, Bek B, Cevik NN, Usanmaz A. The effect of preparation conditions of acrylic denture base materials on the level of residual monomer, mechanical properties and water absorption. J Dent. 1995;23(5):313-8.

9- Harrison A, Huggett R. Effect of the curing cycle on residual monomer levels of acrylic resin denture base polymers. J Dent. 1992;20(6):370-4.

10- Haywood J, Basker RM, Watson CJ, Wood DJ. A comparison of three hard chairside denture reline materials. Part I. Clinical evaluation. Eur J Prosthodont Restor Dent. 2003;11(4):157-63.

11- Jerolimov V, Brooks SC, Huggett R, Bates JF. Rapid curing of acrylic denture-base materials. Dent Mater. 1989;5(1):18-22.

12- Lamb DJ, Ellis B, Priestley D. The effects of process variables on levels of residual monomer in autopolymerizing dental acrylic resin. J Dent. 1983;11(1):80-8.
13- Leles CR, Machado AL, Vergani CE, Giampaolo ET, Pavarina AC. Bonding strength between a hard chairside reline resin and a denture base material as influenced by surface treatment. J Oral Rehabil. 2001;28(12):1153-7

14- Matsumura H, Tanoue N, Kawasaki K, Atsuta M. Clinical evaluation of a chemically cured hard denture relining material. J Oral Rehabil. 2001;28(7):640-4.

15- Minami H, Suzuki S, Minesaki Y, Kurashige H, Tanaka T. In vitro evaluation of the influence of repairing condition of denture base resin on the bonding of autopolymerizing resins. J Prosthet Dent. 2001;28(7):640-4.

16- Neppelenbroek KH, Pavarina AC, Vergani CE, Giampaolo ET. Hardness of heat-polymerized acrylic resins after disinfection and longterm water immersion. J Prosthet Dent. 2005;93(2):171-6.

17- Palmer DS, Barco MT, Billy EJ. Temperature extremes produced orally by hot and cold liquids. J Prosthet Dent. 1992;67(3):325-7.

18- Pavarina AC, Machado AL, Giampaolo ET, Vergani CE. Effects of chemical disinfectants on the transverse strength of denture base acrylic resins. J Oral Rehabil. 2003;30(11):1085-9.

19- Rached RN, Del-Bel Cury AA. Heat-cured acrylic resin repaired with microwave-cured one: bond strength and surface texture. J Oral Rehabil. 2001;28(4):370-5.

20- Revised American Dental Association specification no. 12 for denture base polymers. J Am Dent Assoc. 2001;28(4):370-5.

21- Robinson JG, McCabe JF, Storer R. Denture bases: the effects of various treatments on clarity, strength and structure. J Dent. 1987;15(4):159-65.

22- Schneider RL, Curtis ER, Clancy JM. Tensile bond strength of acrylic resin denture teeth to a microwave- or heat-processed denture base. J Prosthet Dent. 2002;88(2):145-50.

23- Takahashi Y, Chai J, Kawaguchi M. Effect of water sorption on the resistance to plastic deformation of a denture base material relined with four different denture reline materials. Int J Prosthodont. 1998;11(1):4954

24- Takahashi Y, Chai J, Kawaguchi M. Equilibrium strengths of denture polymers subjected to long-term water immersion. Int J Prosthodont. 1999;12(4):348-52.

25- Takahashi Y, Chai J. Assessment of shear bond strength between three denture reline materials and a denture base acrylic resin. Int J Prosthodont. 2001;14(6):531-5.

26- Takahashi Y, Chai J. Shear bond strength of denture reline polymers to denture base polymers. Int J Prosthodont. 2001;14(3):271-5.

27- Tsuchiya H, Hoshino Y, Tajima K, Takagi N. Leaching and cytotoxicity of formaldehyde and methyl methacrylate from acrylic resin denture base materials. J Prosthet Dent. 1994;71(6):618-24.

28- Uzun G, Hersek N. Comparison of the fracture resistance of six denture base acrylic resins. J Biomater Appl. 2002;17(1):19-29.

29- Vallittu PK, Lassila VP, Lappalainen R. Wetting the repair surface with methyl methacrylate affects the transverse strength of repaired heat-polymerized resin. J Prosthet Dent. 1994;72(6):639-43.

30- Vallittu PK, Miettinen V, Alakuijala P. Residual monomer content and its release into water from denture base materials. Dent Mater. 1995;11(6):338-42. 